\title{
Effects of low exposure to inorganic mercury on psychological performance
}

\author{
L Soleo, M L Urbano, V Petrera, L Ambrosi
}

\begin{abstract}
The effects of low exposure to inorganic mercury on psychological performance was investigated: the study groups included eight chronically exposed workers and 20 who were only occasionally exposed. These were compared with a control group of 22 subjects from the same plant who were not exposed to mercury. All subjects were administered the WHO test battery to detect preclinical signs of central nervous system impairment: the battery includes the Santa Ana (Helsinki version) test, simple reaction time, the Benton test, and the Wechsler digit span and digit symbol. In addition, the Gordon test was used to study personality profiles and the clinical depression questionnaire. Urinary mercury was used as indicator for internal dose. To this effect, urinary mercury observed in workers examined from 1979 to 1987 was evaluated. Of the pyschic functions explored by behavioural tests, only short term auditory memory was found to be impaired in the chronically exposed workers ( $<<0.05$ compared with the controls). The chronically exposed workers were also found to be more depressed than those in the two other groups. No changes of visual motor functions were observed. The personality of the occupationally exposed workers was found to be considerably changed compared with that of the control group. On the basis of the results obtained and in view of urinary mercury mean concentrations in the exposed group which were $30-40 \mu \mathrm{g} / 1$ over the years, it is suggested that the TLV-TWA for mercury should be lowered to $0.025 \mathrm{mg} / \mathrm{m}^{3}$ and that the biological urinary exposure indicator for biological monitoring should be $25 \mu \mathrm{g} / 1$.
\end{abstract}

Chronic occupational exposure to inorganic mercury concentrations above the time weighted average

Institute of Occupational Health, University of Bari, Bari, Italy

L Soleo, M L Urbano, V Petrera, L Ambrosi threshold unit value (TLV-TWA) may induce the characteristic signs of chronic intoxication in the form of erethism and static and intention tremor. ${ }^{1-6}$ Chronic exposure to $0.06-0.10 \mathrm{mg} / \mathrm{m}^{3}$ mercury concentrations-for which urinary mercury excretion concentrations of between 60 and $200 \mu \mathrm{g} / 1$ are to be expected, depending on whether the $1: 1$ ratio considered by some authors ${ }^{7-9}$ or the $1: 2$ ratio of the WHO study group are retained-is mostly associated with changes in psychological performance. ${ }^{11-14}$ Conversely, chronic exposure to mercury concentrations around or below $0.05 \mathrm{mg} / \mathrm{m}^{3}$ with urinary mercury excretion around or below $50 \mu \mathrm{g} / 1$ does not seem to produce either the symptoms of chronic mercurialism or impaired psychometric tests. ${ }^{91516}$ Based on these considerations, exposure to mercury vapour concentrations of $0.05 \mathrm{mg} / \mathrm{m}^{3}$ and toxic urinary excretion up to $50 \mu \mathrm{g} / 1$ have been thought to be acceptable. $^{9161819}$

In 1980, however, Zedda et al studied the workers of a fluorescent lamp manufacturing factory who were exposed to mean mercury vapour concentrations of $0.027 \mathrm{mg} / \mathrm{m}^{3}$ (range $0.005-0.145$ ) with urinary mercury excretion of $93.4 \pm 30 \cdot 4 .^{20}$ Electromyography showed early disturbances in the peripheral nervous system that were indicative of subclinical neuropathy. In the light of these findings the authors suggested that the $0.01 \mathrm{mg} / \mathrm{m}^{3}$ concentration should be adopted as the TLV for mercury. Again in 1984, Piikivi et al studied the workers of a chlorine manufacturing plant exposed to inorganic mercury and observed a change in psychological verbal intelligence and memory tests administered to subjects with a mercury urinary excretion of about $50 \mu \mathrm{g} / 1$, or with blood mercury concentrations of $15 \mu \mathrm{g} / \mathrm{l}$, and with ambient mercury estimated at between 0.022 and $0.028 \mu \mathrm{g} / \mathrm{m}^{3}$. On the forms of these findings, the authors suggested that the TLV for mercury should be reduced to $0.025 \mu \mathrm{g} / \mathrm{m}^{321}$.

These data show that in the presence of environmental mercury concentrations below the TLV proposed by ACGIH, preclinical changes may be detected in the central nervous system.

It is the purpose of the present study to make a further contribution to the definition of the relation between low exposure to inorganic mercury and the onset of early changes in the central nervous system-the preferred target organ for the poison. We 
have studied the psychological performance in a group of workers at a fluorescent lamp factory with prolonged exposure to low concentrations of inorganic mercury.

\section{Materials and methods EXPOSURE}

The divided exposure to mercury of the subjects may be divided into two periods: before and after 1979 . That year the environment was considerably improved by means of ad hoc technical solutions, such as an improved system for loading mercury into the lamps, quick removal of broken lamps, and a more rational forced ventilation system. Consequently, mercury concentration was considerably reduced and the hazard was almost exclusively restricted to around the pumps loading the metal into the lamps. These technical improvements were introduced because high mercury concentrations, up to tenfold the TLV, were observed in other departments during the 1979 environmental survey - that is, the warehouse and the holder assembly manufacturing lines where the jobs performed do not involve direct exposure. In fact, it was found that air from the manufacturing lines below was trapped by the forced ventilation system and conveyed to the warehouse and the holder line above. Consequently, whatever mercury contamination occurred as a result of lamp breakage or imperfect operation of the mercury loading pumps would spread over to other departments through the faulty ventilation mechanism.

Exposure was evaluated by determining air mercury in the working environment and by measuring urinary mercury concentrations.

Before 1979 and from 1981 the environment was surveyed only for the mercury loading pumps; the 1979 and 1980 surveys covered all the workplaces along the various lamp manufacturing lines and in the non-manufacturing departments. Industrial hygiene surveys in 1986 and 1987 were carried out by personal samplers and from fixed stations, whereas fixed stations alone had been used in previous years. Ambient air sampling lasted between two and four hours depending on the workplace. The following methods were used to collect the mercury vapour before 1986, two serial porous membrane bubblers containing $0.3 \%$ potassium permanganate solution in $5 \%$ sulphuric acid were used; since 1986 , it has been achieved by adsorption on to a mercury specific solid medium. Atomic absorption with the cold vapour technique was used in all cases to analyse the samples.

Urinary mercury was used as the method of biological monitoring for all workers in the plant. Since 1979, all workers have collected 24 hour urine samples every six months; and an atomic absorption spectrophotometric method was used for analysis.

\section{SUBJECTS}

We examined eight workers (group 1) who had been chronically exposed to inorganic mercury since they were assigned to the mercury loading pumps and 20 workers (group 2) who were employed in other basic tasks along the lamp manufacturing lines and were only occasionally performing the tasks of group 1 . The two groups were then compared with 22 subjects (group 3) from the same plant but not exposed to mercury as their tasks were, essentially, packaging, handling the pallets with the finished product, and storing into the warehouse.

All subjects completed a short questionnaire with questions on their work history and past exposure to mercury; other questions covered family history and the presence or absence in each worker of neuropsychiatric disorders.

\section{BEHAVIOURAL TESTS}

The Gordon personal profile was used to measure the following personality traits: ascendant (A), responsibility and perseverance $(R)$, emotional stability $(E)$, sociability (S) ${ }^{22}$ The test consists of 18 items, scores below the 30th percentile indicate a change in the personality trait being examined.

Simple reaction time ( $S R T$ ) was used to evaluate vigilance and attention. ${ }^{23}$ The test was carried out by sending out 64 light stimuli in six minutes at random intervals. The machine automatically calculates the time elapsed between the appearance and the extinction of the light stimulus which is turned off when the subject presses a push button.

The Benton visual recognition was used to examine recognition memory. ${ }^{24}$ Ten geometrical figures are presented one by one. Each figure is shown for 10 seconds after which the subject is encouraged to identify it from among three more similar figures drawn on a board.

The Santa Ana dexterity test (Helsinki version) examined manual dexterity in both hands (preferred hand, non-preferred hand) and its variables, steadiness, prehension, rotation, perceptive motor coordination, and rapidity. ${ }^{23}$ The test requires the subjects to rotate through $180^{\circ}$ the largest possible number of pegs stuck into the holes of a performance board: time allowed is 30 seconds. The pegs have a square base and their upper face is half white and half red. The test is first carried out with the preferred hand, then with the non-preferred hand, following a winding path.

The following subtests of the Wechsler adult intelligence scale (WAIS) were given ${ }^{25}$ : digit span to measure attention, auditory and short term memory, and digit symbol to evaluate perceptive motor rapidity. A score weighted for age was obtained for each subject. Scores of seven upwards were considered normal.

The clinical depression questionnaire (CDQ) (Ipat 
Table 1 Air mercury concentration at different workplaces over time

\begin{tabular}{|c|c|c|c|}
\hline Year & Sampling stations & $\begin{array}{l}\text { No of } \\
\text { surveys }\end{array}$ & $\begin{array}{l}\text { Mean (range) } \\
\left(\mathrm{mg} / \mathrm{m}^{3}\right)\end{array}$ \\
\hline 1976 & $\begin{array}{l}\text { Pumps feeding } \\
\text { mercury into lamps }\end{array}$ & 4 & $0.121(0.005-0.200)$ \\
\hline \multirow[t]{2}{*}{$\begin{array}{l}1979 \\
1980 \\
1986\end{array}$} & $\begin{array}{l}\text { All departments } \\
\text { All departments } \\
\text { Ring lamps mercury }\end{array}$ & $\begin{array}{l}55 \\
60\end{array}$ & $\begin{array}{l}0.054(0.002-0.498) \\
0.006(0.002-0.183)\end{array}$ \\
\hline & $\begin{array}{l}\text { feeding pumps } \\
\text { U lamps mercury }\end{array}$ & 4 & $0.007(0.004-0.010)$ \\
\hline \multirow{2}{*}{1987} & $\begin{array}{l}\text { feeding pumps } \\
\text { Id: after technical }\end{array}$ & 8 & $0.073(0.010-0.130)$ \\
\hline & improvements & 4 & $0.006(0.004-0.008)$ \\
\hline
\end{tabular}

TLV-TWA 1987-8 (ACGIH): 0.050 mg/m³.

depression scale) was used as a measure of depression. ${ }^{26}$ The test contains 40 items. The score obtained for each subject was subsequently compared with the clinical evaluation scales described in the application handbook. Total item scores are pathological between eight and ten sten.

On average, the tests were adminstered within an hour without following any strict order: the Santa Ana (Helsinki version) test, Wechsler digit span and digit symbol subtests, simple reaction times, and Benton test belong to the test battery now being investigated by WHO to detect preclinical signs of the central nervous system impairment caused by neurotoxic substances. ${ }^{23}$

Statistical analysis was undertaken using analysis of variance to compare means and the chi-squared test to compared frequencies.

\section{Results}

As shown in table 1, ambient mercury concentration decreased as the result of primary preventive measures adopted on the lamp manufacturing lines in 1979. In particular, average mercury concentrations in ambient air dropped from $0.054 \mathrm{mg} / \mathrm{m}^{3}$ in 1979 to $0.006 \mathrm{mg} / \mathrm{m}^{3}$ in 1980 ; exposure to mercury was thus higher in the years preceding 1980 . Until that year, however, subjects in the control group (group 3) were presumably also exposed to mercury vapours due to
Table 2 Age and working years of study groups

\begin{tabular}{|c|c|c|c|}
\hline & \multicolumn{2}{|c|}{ Exposed workers } & \multirow{2}{*}{$\begin{array}{l}\text { Controls } \\
\text { Group } 3 \\
(n=22) \\
M \pm s d\end{array}$} \\
\hline & $\begin{array}{l}\text { Group 1 } \\
(n=8) \\
M \pm \text { sd }\end{array}$ & $\begin{array}{l}\text { Group 2 } \\
(n=20) \\
M \pm s d\end{array}$ & \\
\hline $\begin{array}{l}\text { Age } \\
\text { Years at work }\end{array}$ & $\begin{array}{l}40.6 \pm 4.3^{\star} \\
10 \cdot 3 \pm 2.6^{\star}\end{array}$ & $\begin{array}{l}39 \cdot 8 \pm 7 \cdot 2 \\
12 \cdot 4 \pm 2 \cdot 5\end{array}$ & $\begin{array}{l}38.9 \pm 5.4 \\
12.5 \pm 2.9\end{array}$ \\
\hline
\end{tabular}

the faulty forced ventilation system described earlier.

Table 2 gives the age and duration of employment in the three groups. All the workers are young, mostly in their first employment, with no previous exposure to mercury.

Urinary mercury excretion in the chronically exposed group (group 1) (table 3 ) is higher than in the occasionally exposed group (group 2) in almost all the study years. Urinary mercury in the controls is similar to that observed in the occupationally nonexposed subjects ${ }^{87} 28$ and also observed in our industrial toxicology laboratory during pre-employment medical examinations of workers to be assigned to jobs involving exposure to inorganic mercury.

None of the investigated exposed subjects and controls was found to suffer from neuropsychiatric disorders or to have positive family histories for such disorders.

Of the functions explored by behavioural tests (table 4) short term auditory memory is the most clearly impaired. Moreover this function is more severely impaired in group 1 than in the occasionally exposed workers (group 2).

Subjects in group 1 appear to be more depressed than those in the other groups, although intergroup differences are not significant.

Visual motor functions, examined by the SRT, Benton, Santa Ana, and Digit symbol tests appear well preserved in the exposed workers.

No personality impairment is observed in group 1 subjects compared with the controls if the different Gordon scales are considered separately. If the frequency of subjects with changes in three scales at

Table 3 Mean urinary mercury excretion in exposed workers and in control group during study period

\begin{tabular}{|c|c|c|c|c|c|c|c|c|c|c|c|c|c|}
\hline \multirow[b]{3}{*}{ Year } & \multicolumn{8}{|c|}{ Exposed workers } & \multicolumn{4}{|c|}{ Controls } & \multirow[b]{3}{*}{$F$} \\
\hline & \multicolumn{4}{|c|}{ Group I $(n=8)$} & \multicolumn{4}{|c|}{ Group $2(n \doteq 20)$} & \multicolumn{4}{|c|}{ Group $3(n=22)$} & \\
\hline & Mean & $S D$ & Median & Range & Mean & $S D$ & Median & Range & Mean & $S D$ & Median & Range & \\
\hline $\begin{array}{l}1979 \\
1980 \\
1981 \\
1982 \\
1983 \\
1984 \\
1985 \\
1986 \\
1987\end{array}$ & $\begin{array}{r}38 \cdot 7 \\
24 \cdot 8 \\
19 \cdot 4 \\
42 \cdot 2 \\
43 \cdot 2 \\
25 \cdot 2 \\
9 \cdot 5 \\
28 \cdot 1 \\
18 \cdot 2\end{array}$ & $\begin{array}{r}21 \cdot 3 \\
19 \cdot 6 \\
11 \cdot 7 \\
41 \cdot 2 \\
32 \cdot 5 \\
15 \cdot 9 \\
8 \cdot 1 \\
26 \cdot 1 \\
6.5\end{array}$ & $\begin{array}{r}25 \\
17 \\
13 \\
28 \\
28 \\
18 \\
7 \\
18 \\
18\end{array}$ & $\begin{array}{c}10-70 \\
6-66 \\
9-42 \\
9-138 \\
11-121 \\
11-63 \\
1-23 \\
9-93 \\
9-32\end{array}$ & $\begin{array}{l}13.7 \\
11.2 \\
11.8 \\
20.7 \\
19.2 \\
12.8 \\
13.5 \\
11.9 \\
11.7\end{array}$ & $\begin{array}{r}7 \cdot 3 \\
8 \cdot 7 \\
8 \cdot 5 \\
15 \cdot 7 \\
9 \cdot 2 \\
5 \cdot 9 \\
7 \cdot 2 \\
6 \cdot 7 \\
7 \cdot 4\end{array}$ & $\begin{array}{r}12 \\
8 \\
9 \\
14 \\
20 \\
12 \\
12 \\
10 \\
10\end{array}$ & $\begin{array}{l}3-38 \\
2-31 \\
2-30 \\
6-66 \\
4-45 \\
4-30 \\
5-29 \\
4-29 \\
4-34\end{array}$ & $\begin{array}{r}10 \cdot 5 \\
5 \cdot 6 \\
7 \cdot 2 \\
9 \cdot 4 \\
9 \cdot 3 \\
10 \cdot 2 \\
6 \cdot 8 \\
7 \cdot 5 \\
8.5\end{array}$ & $\begin{array}{l}4 \cdot 9 \\
3 \cdot 2 \\
4 \cdot 4 \\
3 \cdot 3 \\
4 \cdot 5 \\
7 \cdot 6 \\
2 \cdot 8 \\
3 \cdot 4 \\
3 \cdot 6\end{array}$ & $\begin{array}{l}9 \\
5 \\
6 \\
8 \\
8 \\
8 \\
5 \\
7 \\
8\end{array}$ & $\begin{array}{l}2-24 \\
2-13 \\
2-17 \\
5-16 \\
6-20 \\
3-25 \\
3-10 \\
2-15 \\
2-17\end{array}$ & $\begin{array}{l}\mathrm{p}<0.01 \\
\mathrm{p}<0.01 \\
\mathrm{p}<0.01 \\
\mathrm{p}<0.05 \\
\mathrm{p}<0.01 \\
\mathrm{p}<0.05 \\
\mathbf{N S} \\
\mathrm{p}<0.01 \\
\mathrm{p}<0.01\end{array}$ \\
\hline
\end{tabular}


Table 4 Percentage of subjects with changes in behavioural tests given to exposed workers and to the control group

\begin{tabular}{|c|c|c|c|}
\hline \multirow[b]{2}{*}{ Behavioural test } & \multicolumn{2}{|c|}{ Exposed workers } & \multirow{2}{*}{$\begin{array}{l}\text { Controls } \\
\left.\begin{array}{l}\text { Group } 3 \\
(n=22\end{array}\right)\end{array}$} \\
\hline & $\begin{array}{l}\text { Group } 1 \\
(n=8)\end{array}$ & $\begin{array}{l}\text { Group 2 } \\
(n=20)\end{array}$ & \\
\hline \multicolumn{4}{|l|}{ Gordon: } \\
\hline A & $50 \cdot 0$ & $65 \cdot 0$ & $59 \cdot 1$ \\
\hline $\mathrm{R}^{\star}$ & $87 \cdot 5$ & $25 \cdot 0$ & $63 \cdot 6$ \\
\hline $\mathrm{E}$ & 62.5 & $45 \cdot 0$ & $59 \cdot 1$ \\
\hline $\mathrm{S}_{\dagger}^{+}$ & 62.5 & $60 \cdot 0$ & $31 \cdot 0$ \\
\hline SRT & 0.0 & $10 \cdot 0$ & $20 \cdot 0$ \\
\hline Benton & $0 \cdot 0$ & $25 \cdot 0$ & $10 \cdot 0$ \\
\hline \multicolumn{4}{|l|}{ Santa Ana: } \\
\hline D & 0.0 & $37 \cdot 5$ & $10 \cdot 0$ \\
\hline \multirow{2}{*}{\multicolumn{4}{|c|}{ Wechsler: }} \\
\hline & & & \\
\hline Digit span + & $50 \cdot 0$ & $35 \cdot 0$ & \\
\hline Digit symbol & 12.5 & $10 \cdot 0$ & $27 \cdot 3$ \\
\hline Clinical depression questionnaire & $50 \cdot 0$ & $25 \cdot 0$ & $36 \cdot 4$ \\
\hline
\end{tabular}

least is considered, then $62.5 \%$ of the subjects in group 4 were found to have suffered from personality changes, $40.0 \%$ in group 2, and $27.3 \%$ in group 3; the difference between groups 1 and 3 was significant $(\mathrm{p}<0.05)$.

\section{Discussion}

Exposure to inorganic mercury continues to decrease thanks to the preventive measures adopted in the plant which have reduced ambient contamination. On the other hand, failing specific indicators for the effects of contamination, behavioural tests are the only tool with which to monitor the workers exposed to low mercury concentrations and to detect any preclinical signs in the central nervous system. ${ }^{2329}$ The subjects in our series who had the highest urinary mercury excretion also had changes in their short term auditory memory and disorders of personality and mood suggesting depression. These data require further confirmation particularly since our observations were centred on subjects with a fairly steady urinary excretion over the study years despite a remarkable variability between subjects (table 3 ), as shown by the high standard deviation. In each instance the workers were exposed to low inorganic mercury and the amount excreted in their urine did not exceed, on average, $50 \mu \mathrm{g} / 1^{616}$-an amount that is still thought to be acceptable. In this connection disorders of short term auditory memory were not observed by Roels et al in workers exposed to mercury with mean urinary excretion of $51.5 \mu \mathrm{g} / \mathrm{g}$ creatinine, ${ }^{16}$ but were observed by Piikivi et al in workers exposed to mercury with blood mercury concentrations higher than $15 \mu \mathrm{g} / \mathrm{l}^{21}$.

Of the tests administered from the WHO behavioural test ${ }^{23}$ only the Wechsler digit span seems to be sensitive in discriminating workers with low mercury exposure and an average urinary excretion of less than $50 \mu \mathrm{g} / 1$.
The high mercury concentrations present in the work areas until 1980 probably played a major part in producing the behavioural changes in the exposed workers. It also seems likely that subjects in the control group may have been exposed before that year. This could explain the presence of some cases with impaired psychological functions in the control group.

On the basis of our findings that changes in the behavioural tests of subjects with low mercury exposure may be observed with average urinary memory concentrations as low as $30-40 \mu \mathrm{g} / 1$, we suggest that the TLV-TWA should be lowered to $0.025 \mathrm{mg} / \mathrm{m}^{3}$ and that a biological urinary exposure index of $25 \mu \mathrm{g} / \mathrm{l}$ should be used as the standard for biological monitoring.

1 Smith RG, Vorwald AJ, Patil LS, Mooney TF. Effects of exposure to mercury in manufacture of chlorine. Am Ind Hyg Assoc $J$ 1970;31:687-701.

2 Berlin M. Dose-response relationships and diagnostic indices of mercury concentration in critical organs upon exposure to mercury and mercurials. In: Nordberg GF, ed. Effects and dose-response relationships of toxic metals. Amsterdam: Elsevier, 1976:235-45.

3 Friberg L, Nordberg GF. Inorganic mercury. Relation between exposure and effects. In: Friberg L, Vostal J, eds. Mercury in the environment. A toxicological and epidemiological appraisal. Cleveland: CRC Press, 1972:130-40.

4 Foa' V, Caimi L. Patologia da mercurio e suoi composti. In: Sartorelli E, ed. Trattato di medicine del lavoro. Padua: Piccin, 1981:353-76.

5 Vroom F, Greer M. Mercury vapour intoxication. Brain 1972;95:305-18.

6 Foa' V, Bertelli G. Mercury. In: Alessio L, Berlin A, Boni M, Roi $R$, eds. Biological indicators for the assessment of human exposure to industrial chemicals. Luxembourg: EEC. 1986: $28-46$.

7 Bell ZG, Lovejoy HB, Vizena TR. Mercury exposure evaluations and their correlations with urine mercury excretion. 3. Time-weighted average (TWA) mercury exposure and mercury urine levels. $J$ Occup Med 1973;15:501-7.

8 Stopford W, Bundy SD, Goldwater LJ, Bittikofer JA. Microenvironmental exposure to mercury vapor. Am Ind Hyg Assoc $J$ 1978;39:378-84.

9 Gambini G. Correlazioni fra concentrazioni di vapori di mercurio inorganico nell'aria, idrarginuria e sintomi di mercurialismo cronico in un impianto cloro-soda con celle elettrolitiche a catodo di mercurio. Med Lav 1977;68:379-92.

10 World Health Organisation Study Group on Internationally Recommended Health Based Permissible Levels in Occupational Exposure to Heavy Metals. Inorganic mercury. Geneva: WHO, 1979.

11 Smith PJ, Langolf G. The effects of mercury exposure on the performance of a binary classification task. Human Factors 1981;23:701-8.

12 Smith PJ, Langolf GD, Goldberg J. Effects of occupational exposure to elemental mercury on short term memory. $\mathrm{Br} J$ Ind Med 1983;40:413-9.

13 Williamson AM, Teo RKC, Sanderson J. Occupational mercury exposure and its consequences for behaviour. Int Arch Occup Environ Health 1982;50:273-86.

14 Schuckmann F. Study of preclinical changes in workers exposed to inorganic mercury in chloralkali plants. Int Arch Occup Environ Health 1979;44:193-200.

15 Langolf GD, Chaffin DB, Henderson E, Whittle HP. Evaluation of workers exposed to elemental mercury using quantitative tests of tremor and neuromuscolar function. Am Ind Hyg Assoc J 1978;39:976-84.

16 Roels H, Gennart JP, Lauwerys R, Buchet JP, Malchaire J, Bernard A. Surveillance of workers exposed to mercury vapour: validation of a previously proposed biological threshold limit value for mercury concentration in urine. $A m J$ Ind Med 1985;7:45-71. 
17 ACGIH. Threshold limit values for chemical substances in work adopted by the American Conference of Governmental Industrial Hygienist for 1987-88. Cincinnati: ACGIH, 1987.

18 Franco G, Malamani T, Suraci A, Tempini G, Pozzoli L, Candura F. Occupational exposure to mercury vapors below $0.05 \mathrm{mg} / \mathrm{m}^{3}$ in a discharge lamps plant. G Ital Med Lav 1981;3:239-44.

19 Roels HA, Lauwerys RR, Buchet JP, et al. Comparison of renal function and psychomotor performance in workers exposed to elemental mercury. Int Arch Occup Environ Health 1982;50:77-93.

20 Zedda S, Cirla AM, Ratti R, Sala C, Zampollo A. Rischio da mercurio nella fabbricazione di lampade fluorescenti studio clinico e ambientale. G Ital Med Lav 1980;2:187-92.

21 Piikivi L, Hanninen $H$, Martelin T, Mantere P. Psychological performance and long-term exposure to mercury vapors. Scand J Work Environ Health 1984;10:35-41.

22 Gordon LV. Gordon personal profile. Adattamento italiano a cura di Paolo Sambin. Firenze: Organizzazioni Speciali, 1979.

23 Johnson B, Baker E, Gilioli R, et al. Prevention of neurotoxic illness in working population. New York: John Wiley, 1987.

24 Benton AL. The revised visual retention test. New York: Psychological Corporation, 1974.

25 Wechsler D. Scala d'intelligenza Wechsler per adulti (WAIS). Firenze: Organizzazioni Speciali, 1986.

26 Krug SE, Laughlin JE. Questionario di autovalutazione CDQ (Ipat Depression Scale). Florence: Organizzazioni Speciali, 1979.

27 Cigna-Rossi L, Clemente GF, Santaroni G. Mercury and selenium distribution in a defined area and in its population. Arch Environ Health 1976;31:160-5.

28 Lie A, Gundersen N, Korsgaard KJ. Mercury in urine. Sex, age and geographic differences in a reference population. Scand $J$ Work Environ Health 1982;8:129-33.

29 Cassitto MG, Gilioli R. Mercurio e sistema nervoso. G Ital Med Law 1980;2:181-6.

Accepted 3 April 1989
All manuscripts submitted to the $B r J$ Ind Med should conform to the uniform requirements for manuscripts submitted to biomedical journals (known as the Vancouver style)

The $B r J$ Ind Med, together with many other international biomedical journals, has agreed to accept articles prepared in accordance with the Vancouver style. The style (described in full in Br Med J, 24 February 1979, p 532) is intended to standardise requirements for authors.

References should be numbered consecutively in the order in which they are first mentioned in the text by Arabic numerals above the line on each occasion the reference is cited (Manson ${ }^{1}$ confirmed other reports $\left.{ }^{2-5} \ldots\right)$. In future references to papers submitted to the $\mathrm{Br} J$ Ind Med should include: the names of all authors if there are six or less or, if there are more, the first three followed by $e t$ al; the title of journal articles or book chapters; the titles of journals abbreviated according to the style of Index Medicus; and the first and final page numbers of the article or chapter.

Examples of common forms of references are:

I International Steering Committee of Medical Editors. Uniform requirements for manuscripts submitted to biomedical journals. Br Med J 1979:1:532-5.

2 Soter NA, Wasserman SI, Austen KF. Cold urticaria: release into the circulation of histamine and eosino-phil chemotactic factor of anaphylaxis during cold challenge. $N$ Engl $J$ Med 1976;294:687-90.

3 Weinstein L. Swartz MN. Pathogenic properties of invading micro-organisms. In: Sodeman WA Jr. Sodeman WA, eds. Pathologic physiology: mechanisms of disease. Philadelphia: W B Saunders. 1974:457-72. 